\title{
Annerledes tenkende angstfri
}

\author{
Hun er bygdejenta og kunstnerspiren som ble kirurg og toppforsker ved Harvard. Hun ledet \\ mammografiprogrammet og fant ut at det ikke virker. Mette Kalager synes man bør tenke \\ selv og bøye seg for fakta.
}

Til avtalt tid en lys fredagskveld i mai ankommer jeg villaen i Bærum. Jeg blir hjertelig geleidet inn i den åpne stuen til Mette Kalager og hennes forskermann Michael Bretthauer. Men det er noe som ikke stemmer. Det er mange mennesker der, de drikker champagne, skravler og ler, det er feststemning. Har Mette glemt at hun skal intervjues? Jeg later som ingenting, finner en plass i sofaen, hilser på smilende gjester. Mette går til flatskjermen som vender mot oss, hun er elegant $\mathrm{i}$ tettsittende kjole som matcher glitteret i blå lyskasterøyne. Hun snakker, og jeg begynner å skjønne hva lyset i øynene, champagnen og feststemningen handler om.

- Du vet, Edvin, at jeg og forskergruppen min har jobbet knallhardt med en søknad til Forskningsrådet om å bli Senter for fremragende forskning. Derfor måtte vi utsette intervjuet til nå. Vi er i finalerunden, hvor 34 av 150 miljøer konkurrerer. Vi har jobbet dag og natt for å bli ferdige. Disse menneskene er forskergruppen min, jeg er så stolt av dem. Vi har blant annet laget en film for å promotere prosjektet vårt, kan du tenke deg å se den, vi har bare sett den to ganger allerede?

Alle ler, skjermen lyser opp, og en lettfattelig animasjonsfilm viser på ett minutt hvordan et forskningssenter i Oslo skal bli en global ressurs for klinikere og pasienter ved å prosessere internasjonale data fra masseundersøkelser for kreft.

Mette forteller: - Da en av samarbeidspartnerne fikk høre at vi skulle bruke film for å forklare konseptet, mente han at det var å undervurdere juryens intellekt. Beslutninger tas ikke med intellektet alene, svarte jeg.

Gjestene drar smilende ut i sommerkvelden. Det blir stille i det store rektangulære rommet hvor to glassvegger slipper skumringen inn. Vi setter oss.

- Jeg hører du har drevet research om meg? sier Mette.
- Ja, men det har ikke dukket opp noe saftig sladder ennå, svarer jeg.

- Jeg er så innmari åpen at det vel ikke er stort å hente, ler Mette.

- Er du veldig skikkelig?

- I de store linjene, ja. Men i det hverdagslige kan jeg være fullstendig fjern. Jeg glemmer ofte tid og sted. Kan se film til klokken fem om morgenen selv om jeg skal holde et stort foredrag neste dag. Da jeg jobbet med søknaden, var jeg i en boble i flere uker. Ante ikke om vi hadde melk og smør

\section{«Beslutninger tas ikke med intellektet alene»}

i huset, det har vi alltid når Michael er hjemme. Om morgenen så jeg at vi ikke hadde brød, ungene kunne ikke smøre niste. Så kjøpte jeg kanelboller og kjørte til skolen med dem. Det er jo ikke sånn man skal gjøre. Eller vi drar på badeferie, og jeg glemmer badedraktene. Så må vi kjøpe nye. Slik er det å leve med meg. Og jeg tror ikke det er så mye jeg kan gjøre med det.

\section{Ting ordner seg}

- Hm. Du er altså oppsiktsvekkende fri for unødvendig angst?

- Ja det er sant, jeg er helt fri for angst. Jeg trenger ikke å vite lenge $\mathrm{i}$ forveien når jeg skal fly og hvor jeg skal bo. Alt slikt ordner seg. Jeg kan ikke huske sist jeg tenkte at noe ikke ville ordne seg. Det kan jo medføre noen kanelbollesituasjoner, men stort sett er det fint for meg. Av og til opplever jeg likevel at folk har lyst å sette meg på plass. Jeg får kritikk for å si ting som de er. - Du provoserer kanskje mennesker som har snusfornuften som livssyn? De som er overbevist om at en god dose bekymring i hverdagen simpelthen opprettholder verden?

Mette humrer.

- Har du ikke sjenanse eller autoritetsangst heller? Hva om du skulle hilse på Obama?

- Da ville jeg fått puls. Jeg blir aktivert når jeg skal holde foredrag og slikt. Men ikke fordi jeg er redd for at det skal gå galt. Jeg er ikke redd for kritikk, og jeg bryr meg ikke om folk med makt blir sinte. For jeg er ikke en klatrer, jeg skal ikke til topps i noe system. Jeg vil bare holde på med mine ting. Akilleshælen er at jeg går trøtt hvis jeg ikke får nye utfordringer.

Latinsk temperament på Krøderen

Det er visstnok en overhyppighet av kreativ genialitet blant nordmenn med oppvekst i små bygder, anekdotisk underbygd av en perlerad av forfattere og kunstnere fra Henrik Ibsen til Jon Fosse. En foreslått forklaring er at mangel på likesinnede i ungdomstiden virker herdende, annerledestenkeren blir vant med å stå alene med sin virkelighetsoppfatning og sine drømmer, mer eller mindre uanfektet av hva «alle» $\mathrm{i}$ bygda mener. Mette Kalagers foreldre var 18 år da hun ble født inn i det lille samfunnet Krøderen. Hun bodde tett innpå besteforeldrene og var lenge eneste barnebarn, omsorgsfullt omsluttet av to generasjoner kjærlige voksne. Familien var «annerledes», det visste alle. Det var industriarbeidere og håndverkere der, men også lærere og kunstnere.

- Jeg husker TV-filmer med utagerende italienske storfamilier, alle syntes det var så eksotisk. Jeg skjønte ikke hva som var så spesielt. Er det ikke sånn livet er? Liv og røre, høyt og lavt, alt tas opp, det skjer noe hele tiden? Mormor hadde ti søsken. To av dem ble ordførere, mange var temmelig sprø. Det kunne være fest, alle var sammen og alt var fint, så kunne en onkel plutselig reise seg, glassene fløy, og vi tenkte «hæ, hva er det som skjer nå liksom?». Det kunne 


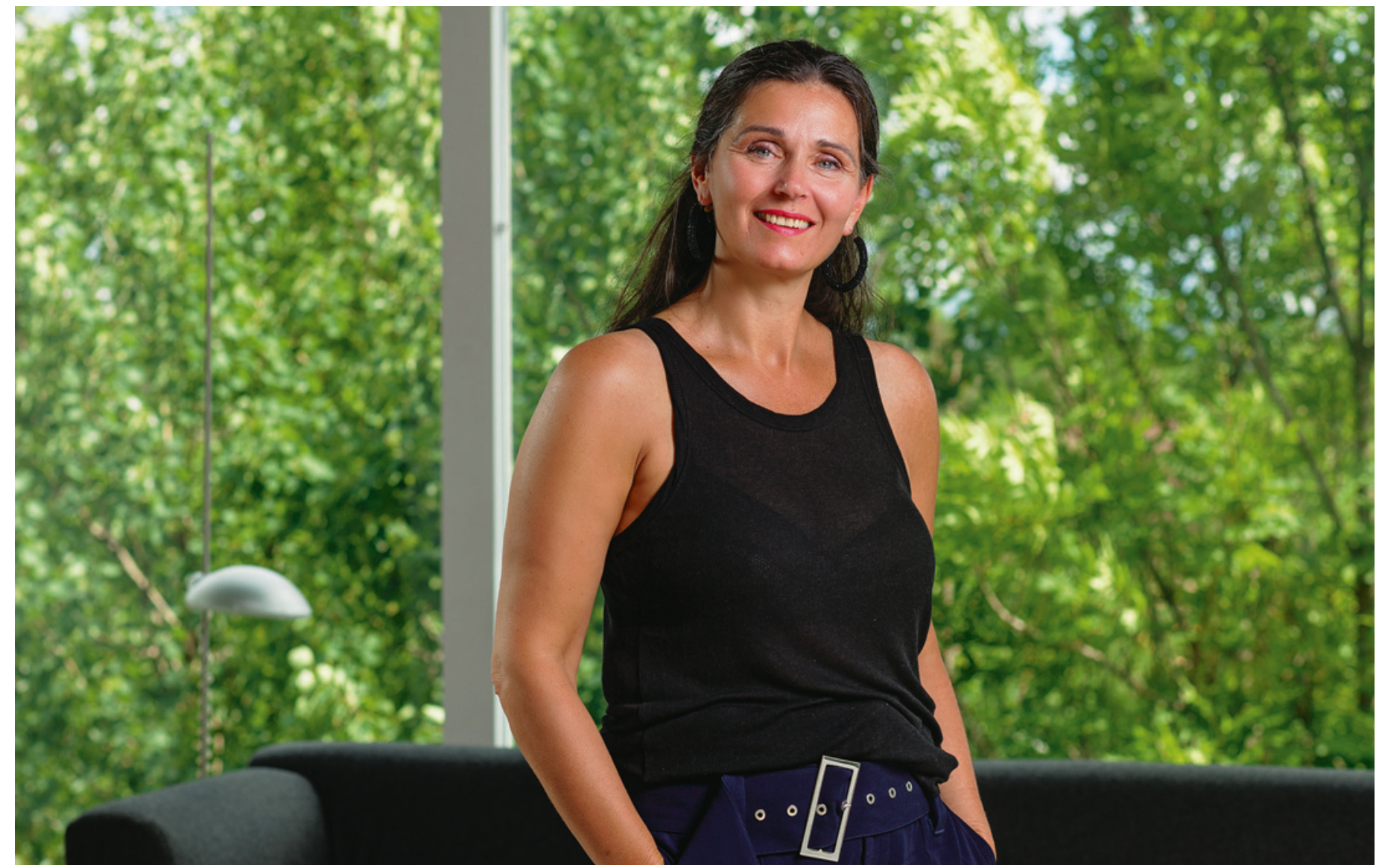

Foto: Niklas Lello

\section{Mette Kalager}

Født 1967, oppvokst på Krøderen

i Buskerud

- Russerevysjef, ble nesten profesjonell danser

- Jobbet syv år som kirurg

- Ledet Mammografiprogrammet fra 2004 til 2007

- Internasjonal forskerkarriere innen screening

- Førsteamanuensis ved Universitetet i Oslo, leder gruppe for Klinisk Effektforskning bli intens krangling om en eller annen bagatell, og i neste øyeblikk var det felespill og sang og latter. Å være en unge som bare fikk henge rundt i det der, det var nok et privilegium. Jeg tror det er feil at alt skal være så harmonisk og beskyttet og pedagogisk, at unger ikke må oppleve at voksne er rare og har sterke følelser. Våre tre døtre får være med på det meste. Livet er en kaotisk treningsleir, og barna må delta for å mestre.

\section{Kunst og kirurgi}

Mette ville tidlig at foreldrene skulle flytte til et mer spennende sted, hun kjedet seg. Mor forteller at lille Mette så ut av kjøkkenvinduet og sa: «Jeg sitter i en glasskule og ser på alt rundt meg uten å være der selv.» Syv år gammel leste hun boken Jenter kan. Hun var best på skolen, alltid tillitsvalgt, dyktig i sport og kunst, ble sjef for russerevyen. Skulle hun bli kunstner eller akademiker? Mette studerte dans og økonomi i Arizona, så medisin i Oslo. Hun ville bli allmennlege, tok kirurgi sideutdanning og ble forelsket i kirurgien.

- Jeg egner meg som kirurg. Selv om jeg er god til å tenke, er jeg også god til å ta beslutninger. Det koster meg ingenting. Og det kan være store ting, en trafikkulykke som kommer inn, og vi må bestemme oss for å amputere, for eksempel.

Nå har Michael satt seg ned med oss.

- Mette er også uvanlig usentimental.

Hun er veldig empatisk, men fnyser av småting. Jeg husker en 18-åring fra turnustiden, han satt $\mathrm{i}$ kassen på en butikk og kom på akuttmottaket etter et fall, han hadde fått en «greenstick»-fraktur i radius.

Nå ler Mette.

- Må du virkelig fortelle den historien?

Jeg ser en humoristisk blikkveksling mellom ektefellene, så fortsetter Michael:

- Gutten ba om sykmelding, og jeg skulle til å si ja. Da brøt Mette inn. «Kan du bruke venstrearmen i kassen?» Ja, han kunne jo det. Så ble det ingen sykmelding!

\section{Den fremste drar tyngst}

- Hva er spesielt med deg, Mette Kalager?

- Jeg mangler et godt svar. Jeg gjør ingen heroiske ting. Men jeg er en modig person, veldig ærlig og oppriktig. Jeg har sterk integritet. Hvis noe er galt, så sier jeg fra.

Nå tar Michael ordet. Han lener seg forover og ser på meg.

- Det er noe jeg vil si, fordi Mette ikke sier det selv. Mette er ekstremt smart. - Jeg trodde du var smart også, Michael? 
- Nei, ikke slik som henne.

- Det er nok sant, for å være helt ærlig. Det er nok noe jeg kan og ikke han, sier Mette.

Michael smiler. - Der kan du høre hva jeg må leve med! Hun bekrefter det, ikke sant, mens en dydig kone skulle sagt «Nei, det er ikke sånn, Michael».

Vi ler. Jeg er havnet i en samtale hvor janteloven ikke finnes. Det er en uskyld over de to forskerne, jeg føler meg som i Edens hage før syndefallet.

- Og med denne smartheten følger det noe som kan ligne arroganse. Mette orker ikke å diskutere med folk som ikke forstår det opplagte. Man får det i perspektiv i utlandet. Vi dro fra lille Oslo til Harvard. Det er jo der de smarte finnes, liksom. Vi jobbet med Marvin Zelen, den store stjernen i moderne biostatistikk. Han tok meg til side og sa «she is probably the smartest person I ever met». Han fortalte at han brukte to år på å regne seg frem til en sammenheng i forskningsdata som Mette intuitivt skjønte, og som han lenge mente var feil, forteller Michael.

- Forklar, hva handler det om?

- I dette tilfellet var det matematiske sammenhenger i store datamaterialer. Mette ser gjerne ting som andre oppdager ti år senere. I mellomtiden får hun motstand.

- Ja, det har vært litt slitsomt faktisk. Men heldigvis er det bedre nå, de som kjenner meg, stoler på det jeg sier. Jeg må ikke kjempe lenger for å få folk med på ting. - Blir du stolt?

Tenkepause.

- Ja. Men dette er jo ikke nytt for meg, jeg har jo alltid vært der. Det har noen ulemper. Den som flyr først i gåseplogen, er ensom og drar tungt. Og det er ikke mange som ser deg, kanskje bare to. Er du midt i flokken, er det kanskje hundre som ser at du har rett og klapper deg på skulderen.

\section{Flere språk i akademia}

- Jeg har en dobbelthet i meg. Jeg kan være iskaldt rasjonell, men kjenner meg ofte som en kunstner. Da vi laget denne filmen, kjente jeg at «ja, vi snakker samme språk». Med akademikere føler jeg av og til det motsatte, de er ikke med på lek, jeg savner kreativt liv. Det hender jeg tenker «hvorfor fortsatte jeg ikke med dans, så kunne jeg blitt koreograf?» Det er så mye vi kan oppnå ved å bruke andre virkemidler enn ord, men akademia er svak på det. - Du skulle ta deg tid til å lese The act of creation av Arthur Koestler. Han viser at vitenskap, kunst og humor er grunnleggende like i sin struktur og befrukter hverandre. En leken akademiker vil lettere få nye ideer, lytte til innspill fra andre og unngå å bli fanget i stive forestillinger. Medisinens historie er full av triste eksempler på selvgod akademisk fanatisme. Klassikeren er jo doktor Semmelweiss og kollegene som nektet å tro på tallene som beviste at håndvask mellom obduksjon og visittgang reduserte dødsfall av barselfeber. Semmelweiss ble frosset ut.

\section{Underkjent}

- Du vet at doktoravhandlingen min ikke ble godkjent?

Vi er to timer ut i samtalen, Michael har sovnet et sted i huset, Isolde på 13 har nettopp gått til en venninne etter å ha hilst pent, svinset hyggelig på kjøkkenet bak oss og bemerket hvor fin mor er med nyklippet

\section{«Livet er en kaotisk treningsleir»}

hår. Utenfor de store vinduene er det nok mørke til at stearinlysene skinner, og jeg må streve for å ta notater. Men jeg ser øynene til Mette, ser at de blå lyskasterne er slått av, et mørke der også.

- Det er nok det vondeste jeg har opplevd. Jeg kom ivrig og stolt fra Harvard med flott forskning på mammografidataene til Kreftregisteret, tre sterke artikler med internasjonale toppforskere, én publisert i New England Journal of Medicine. Vi hadde funnet ut at screening ikke var så viktig for brystkreftoverlevelse som vi hadde trodd, og dødeligheten falt like mye i kontrollgruppen. Funnet og konklusjonen var overraskende, vi måtte omstille oss og tenke nytt. Men man må jo forholde seg til fakta, det er derfor vi har vitenskap, sier Mette.

- Det falt meg ikke inn at den akademiske verden skulle reagere irrasjonelt og prøve å stanse arbeidet mitt. Først ble avhandlingen ikke godkjent, jeg måtte gjøre store endringer uten at jeg egentlig forsto hvorfor. Så ble også den nye versjonen underkjent, og fremdeles kunne vi ikke se hva som var galt med metodene. Jeg ble mer lei meg enn jeg kan huske å ha vært, og forvirret. Jeg måtte be om hjelp, det er ikke lett for meg. Jeg fant psykiateren Øyvind
Ekeberg, en svært klok mann. Så fikk jeg Legeforeningens jurister til å ta saken. Etter hvert kom rektor ved Universitetet i Oslo på banen, det ble nedsatt en ny komité, og ting ordnet seg. Jeg fikk disputere i 2012. Men $i$ to år følte jeg meg utstøtt, sviktet, usikker på egen dømmekraft - var det virkelig noe galt med tenkeevnen min? Jeg hadde funnet frem til forskning som plattform og mening for yrkeslivet, og så ble alt kastet overende - selvrespekt, identitet, fremtid.

Vi sitter stille, flammen blafrer.

\section{NICER}

- Du var altså leder for mammografiprogrammet. Vil du selv gå til mammografi når du blir innkalt?

- Nei, det tør jeg ikke.

- Hvorfor?

- Det er gjort screening av over en halv million kvinner i loddtrekningsforsøk. Totaldødeligheten påvirkes ikke. Man finner kreft, men man redder ikke liv. Av 10000 mammograferte får 377 påvist brystkreft. Evalueringen sier at 27 av disse reddes fra å dø. Men fem ganger så mange - 142 kvinner - blir overdiagnostisert. Det vil si at de får kreftbehandling for svulster de aldri ville merket noe til. Jeg vil ikke bli en av dem. Kanskje er det behandlingsbivirkninger som gjør at den screenede gruppen ikke lever lenger. Hadde man visst dette da programmet ble planlagt, hadde vi nok ikke hatt mammografiscreening i Norge i dag. Politikerne våger ikke å legge det ned, de skal jo velges. Men vi må slutte å innkalle kvinner til mammografi med fastsatt klokkeslett. Det ligger et villedende budskap i dette, om at det er din egen skyld hvis du får brystkreft og ikke gikk til screening. - Hva mener du om befolkningsundersøkelser generelt?

- Ingenting. Hvert felt har sin egen epidemiologi, vi må se på tallene. Koloskopi ser ut til å være nyttig, cervixcytologi også Vi trenger forskning som kan se på kompleksiteten på hvert enkelt felt, hvor biologien, demografien og den medisinske teknologien gir ulike forutsetninger. Det er dette jeg vil jobbe med hvis vi blir et Senter for fremragende forskning. Vi har kalt det Norwegian Institute of Cancer Screening Evidence and Research. Og som en av mine medarbeidere sa: «Isn't that NICER?»

\section{Edvin Schei}

edvin.schei@uib.no 